\title{
Antifungal Activity of Compounds Isolated from Bamboo Vermicompost against Rhizoctonia solani AG1-IB
}

\author{
Xiaodong You ${ }^{1,2 *}$, Daigo Wakana ${ }^{2}$, Kazuki Ishikawa ${ }^{2,3}$, Tomoo Hosoe ${ }^{2}$, Motoaki Tojo ${ }^{1}$ \\ ${ }^{1}$ Graduate School of Life and Environmental Sciences, Osaka Prefecture University, Sakai, Osaka, Japan \\ ${ }^{2}$ Department of Organic Chemistry, Hoshi University, Shinagawa, Tokyo, Japan \\ ${ }^{3}$ Research Institute of Pharmaceutical Sciences, Musashino University, Nishitokyo-Shi, Tokyo, Japan \\ Email: ${ }^{\star x i a o d o n g y o u @ h o t m a i l . c o m ~}$
}

How to cite this paper: You, X.D., Wakana, D., Ishikawa, K., Hosoe, T. and Tojo, M. (2019) Antifungal Activity of Compounds Isolated from Bamboo Vermicompost against Rhizoctonia solani AG1-IB. Advances in Microbiology, 9, 957-970. https://doi.org/10.4236/aim.2019.912061

Received: October 29, 2019

Accepted: November 24, 2019

Published: November 27, 2019

Copyright (c) 2019 by author(s) and Scientific Research Publishing Inc. This work is licensed under the Creative Commons Attribution International License (CC BY 4.0).

http://creativecommons.org/licenses/by/4.0/

\begin{abstract}
Vermicompost has become a promising alternative to chemical pesticide because of its disease suppression effect during these decades. However, the mechanisms by which vermicompost suppress plant disease are not well-understood. Antifungal compounds, which are released by beneficial organisms in the vermicompost, may play an important role in inhibiting plant pathogens; however, these mechanisms have not been widely examined. In this study, Sterilized Water Extracts of bamboo vermicompost (SWE), using a $0.22-\mu \mathrm{m}$ cellulose acetate filter, significantly $(P<0.05)$ inhibited the mycelium growth of Rhizoctonia solani AG1-IB on a Potato Dextrose Agar (PDA) plate. This suggests that antifungal compounds are present in bamboo vermicompost. The ethanol acetate (EtOAc) crude extracts of bamboo vermicompost showing antifungal activity were further separated. Two compounds were isolated from the EtOAc fraction of bamboo vermicompost and characterized as ergosterol peroxide (1) and (22E, $24 R)-5 \alpha, 8 \alpha$-epidioxyergosta6,9(11),22-trien-3 $\beta$-ol (2). Their chemical structures and mass spectra were determined by nuclear magnetic resonance and mass spectrometry analyses. Ergosterol peroxide tested at 150, 300,600, and $900 \mu$ g showed $13 \%, 22 \%$, $34 \%$, and $53 \%$ mycelial growth inhibition against $R$. solani AG1-IB, respectively. Because EtOAc crude extracts of the initial substrate materials of bamboo vermicompost did not inhibit mycelium growth of $R$. solani AG1-IB, antifungal compounds in the vermicompost may be released by microbes but not from the original substrates during vermicomposting.
\end{abstract}

\section{Keywords}

Antifungal Compound, Ergosterol Peroxide, Vermicompost, Rhizoctonia solani AG1-IB 


\section{Introduction}

Seedling damping-off diseases caused by Rhizoctonia solani are economically important in a broad range of crops worldwide [1] [2]. This pathogen is difficult to control because of its ability to persist under adverse soil conditions, as it contains structures such as sclerotia that survives for several years in the absence of host crops and exhibits saprophytic activity, a wide host range, and versatility [3]. Although fungicide application is effective for suppressing such diseases, frequent use of fungicides can result in the emergence of fungicide-resistance strains, leading to undesirable effects on human health and environmental safety [4] [5]. Therefore, alternative strategies for controlling this disease are urgently needed.

Vermicompost is a composting product of accelerated biodegradation of organic matter by earthworms and their associated microbes through non-thermophilic decomposition. Recently, several studies have focused on the potential of vermicompost to suppress soil-borne plant pathogens including $R$. solani [6] [7]. The activities of microbial antagonists present in vermicompost are considered as an important mechanism for disease suppression. Several antagonistic bacteria and fungi, such as Bacillus subtilis, Streptomyces spp., Trichoderma sp., and Aspergillus sp., were isolated from vermicompost and shown to suppress soil-borne plant pathogens [8] [9] [10]. These microbes are well-known to produce diversity bioactive compounds including antifungal compounds. Release of antifungal compounds by these microbes into the vermicompost may play an important role in inhibiting plant pathogens, which has not been widely examined. Understanding the chemical factors of how vermicompost suppresses soil-borne plant pathogens may promote effective utilization of the vermicompost. In our previous studies, a vermicompost produced from moso-bamboo (Phyllostachys edulis (Carrière) J. Houz.) showed the ability to suppress cucumber damping-off caused by $R$. solani AG1-IB [11].

In the present study, we examined the effects of water extracts of bamboo vermicompost, sterilized with a Corning $0.22-\mu \mathrm{m}$ cellulose acetate filter (SWE), on $R$. solani AG1-IB mycelium growth on potato dextrose agar (PDA). Although the SWE did not contain microbes in the bamboo vermicompost, it significantly $(P<0.05)$ inhibited the mycelium growth of $R$. solani AG1-IB. This suggests that the SWE contained antifungal compound(s). This study was conducted to isolate the antifungal compound(s) from the bamboo vermicompost, determine the chemical structures and mass spectra by nuclear magnetic resonance (NMR) and mass spectrometry analyses, and evaluate the suppressive effect on $R$. solani AG1-IB.

\section{Materials and Methods}

\subsection{Experimental Instruments}

${ }^{1} \mathrm{H}$ and ${ }^{13} \mathrm{C}$ NMR spectra were recorded using a Bruker AVANCE-400 spectrometer $\left(400.13 \mathrm{MHz}\right.$ for ${ }^{1} \mathrm{H}, 100.61 \mathrm{MHz}$ for ${ }^{13} \mathrm{C}$; Bruker Biospin K.K., Kanagawa, 
Japan). Chemical shifts ( $\delta$ ) were measured in ppm using tetramethylsilane as an internal standard. Samples were analyzed with PDA-HPLC using a PU-980 and PU-1580 pump (JASCO Co., Ltd., Tokyo, Japan) and Inertsil ODS-3 column (5 $\mu \mathrm{m}, 4.6 \mathrm{~mm} \times 250 \mathrm{~mm}$; GL Science, Inc., Tokyo, Japan) maintained at a temperature of $30^{\circ} \mathrm{C}$ using a CO-2065 Plus column oven (JASCO Co.) and equipped with a MD-2010 Plus photodiode array (JASCO Co.). Compounds were isolated using a reverse-phase MPLC system with an SSC-3160 pump (Senshu Scientific Co., Ltd., Tokyo, Japan) and ULTRA PACK ODS-SM-50A column $(50 \mu \mathrm{m}, 300$ $\times 11 \mathrm{~mm}$; Yamazen Corp., Osaka, Japan) equipped with a YRU-8883 RI-UV detector (Shimamuratach, Tokyo, Japan), and reverse-phase HPLC system with a LC-20AT prominence pump (Shimadzu Corp., Kyoto, Japan) and a Inertsil ODS-3 column $(5 \mu \mathrm{m}, 250 \times 4.6 \mathrm{~mm}$, GL Science Inc., Tokyo, Japan) in a CO-965 column oven (JASCO Co., Ltd., Tokyo, Japan) equipped with a SPD-20A UV detector (Shimadzu Corp., Kyoto, Japan).

\subsection{Materials}

Bamboo vermicompost was produced as described previously [11]. The initial substrate materials of bamboo vermicompost contained moso-bamboo shoots powder and kudzu vines (Pueraria lobata (Willd) Ohwi, $<10 \mathrm{~cm}$ in length). Moso-bamboo shoots were cut from an abandoned bamboo forest in Eboshi-yama, Kawachinagano City, Japan. Kudzu vines were collected from the Nakamozu Campus of Osaka Prefecture University. Earthworms used were Eisenia fetida Savigny (commercial name: "Kumatarofutomushi") and purchased from Fishing Azumino Company, Azumino, Japan. Rhizoctonia solani AG1-IB isolate SLS1 (MAFF244980) used in the study was provided by Dr. Misawa Tomoo (Hokkaido Research Organization, Japan). This isolate was recovered from diseased spinach in Hokkaido, Japan [12].

\subsection{Preparation of SWE}

The water extracts of bamboo vermicompost were prepared by mixing the samples with distilled water at a ratio of 2:3 (v/v) followed by active aeration with a small air pump at $20^{\circ} \mathrm{C}$ for $24 \mathrm{~h}$ according to a previous study [13] with some modifications. The supernatant of the water was filtered through a filter paper (Whatman No.1, $9 \mathrm{~cm}$ in diameter, GE Healthcare UK Ltd., Little Chalfont, UK) to obtain water extract of bamboo vermicompost, followed by filter-sterilization through a $0.22 \mu \mathrm{m}$ cellulose acetate filter (Corning Inc., Corning, NY, USA) to obtain sterilized water extracts of bamboo vermicompost (SWE).

\subsection{Effect of SWE Treatment on Mycelium Growth Rate of $R$. solani AG1-IB}

One milliliter of SWE was pipetted onto a PDA plate and expanded over the entire surface with a sterilized glass rod according to a previous study [13] with some modifications. A $5 \mathrm{~mm}$-diameter agar plug with 7-day-old mycelium of $R$. 
solani AG1-IB was placed on the center of the PDA plate and incubated in the dark at $25^{\circ} \mathrm{C}$. Sterilized distilled water was used as a control. Mycelium growth was evaluated by visual measurement of the colony radius at $24 \mathrm{~h}$ intervals for 2 days. The experiments were repeated five times.

\subsection{Isolation of Antifungal Compounds from Bamboo Vermicompost}

The separation scheme of the antifungal compounds from bamboo vermicompost is shown in Figure 1. Ten liters of bamboo vermicompost were extracted with acetone, and the organic layer was evaporated. The resulting extracts were suspended in $\mathrm{H}_{2} \mathrm{O}$ and extracted with EtOAc, and then the organic layer was evaporated in vacuo for further analysis. The EtOAc extracts $(1.67 \mathrm{~g})$ were used to determine their antifungal activities against $R$. solani AG1-IB by the paper disc diffusion method [14]. The EtOAc extracts were then chromatographed on Sephadex LH-20 (GE Healthcare Bio-Sciences, Uppsala, Sweden; solvent system: hexane- $\mathrm{CHCl}_{3}(1: 4 ; 200 \mathrm{~mL}), \mathrm{CHCl}_{3}$-acetone $(3: 2 ; 200 \mathrm{~mL}),(1: 4 ; 200 \mathrm{~mL})$, acetone $(200 \mathrm{~mL})$ and $\mathrm{MeOH}(1000 \mathrm{~mL})$ to collect nine fractions: $2.6 \mathrm{mg}$ for Fr. A, $233.3 \mathrm{mg}$ for Fr. B, $57 \mathrm{mg}$ for Fr. C, $136.4 \mathrm{mg}$ for Fr. D $355.1 \mathrm{mg}$ for Fr. E, 105 mg for Fr. F, $169 \mathrm{mg}$ for Fr. G, $113 \mathrm{mg}$ for Fr. H, $495.8 \mathrm{mg}$ for Fr. I. The nine fractions were used to determinate the antifungal activities of these samples against $R$. solani AG1-IB by paper disc diffusion method [14].

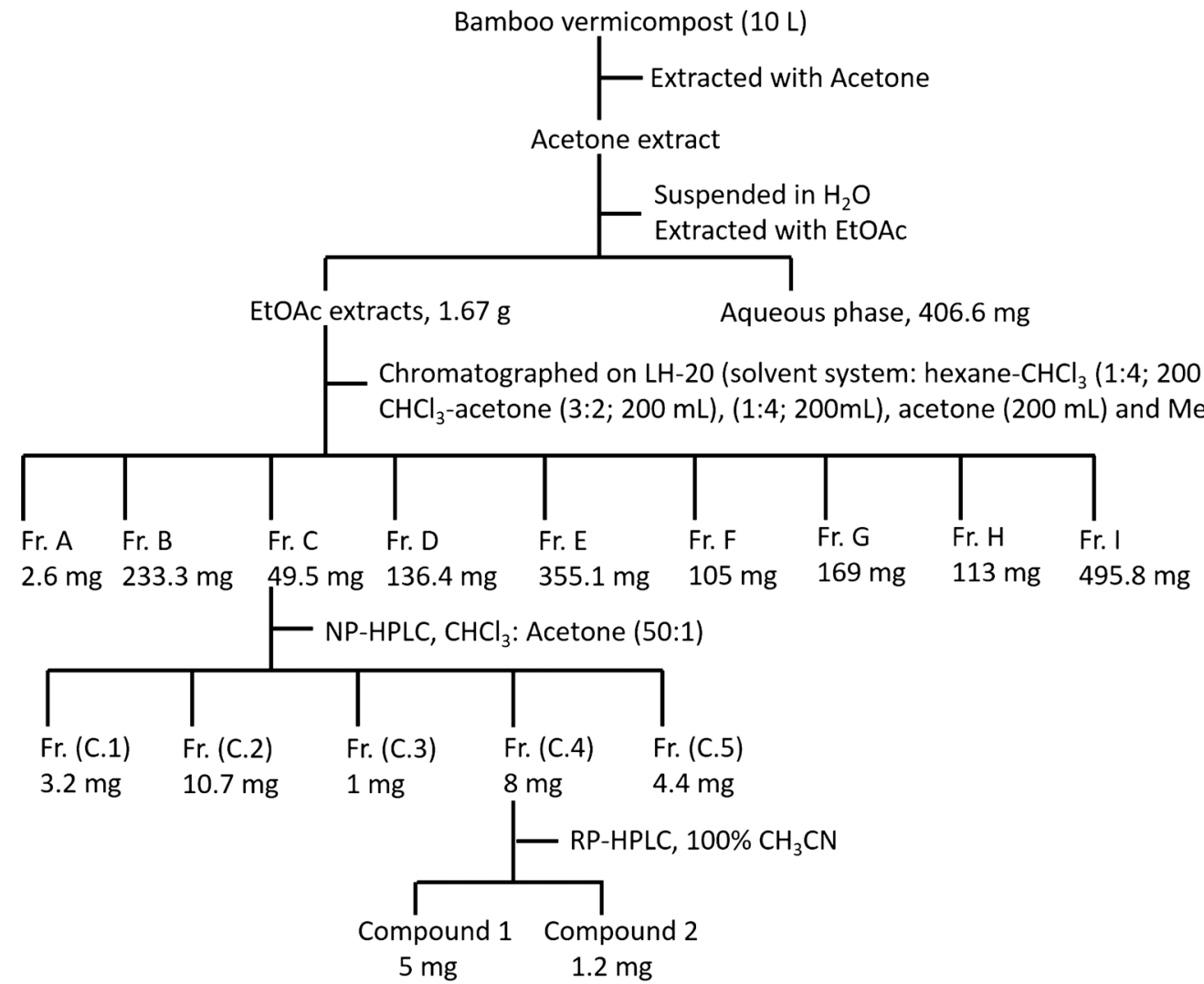

Figure 1. Separation scheme of compounds from bamboo vermicompost. 
The fraction (C) showing two major peaks was further isolated by normalphase-HPLC with $\mathrm{CHCl}_{3}$ : acetone to produce five fractions (Fr. C.1 - C.5). The fraction (C.4, $8 \mathrm{mg}$ ) which contained the two major peaks was further purified by HPLC on octadecylsilyl (ODS) and eluted with $100 \% \mathrm{CH}_{3} \mathrm{CN}$ to obtain compounds $1(5.0 \mathrm{mg})$ and $2(1.2 \mathrm{mg})$. Their chemical structures and mass spectra were determined by NMR and mass spectrometry as described previously [15].

\subsection{Inhibitory Effect of Ergosterol Peroxide (1) Isolated from Bamboo Vermicompost on Mycelium Growth of $R$. solani AG1-IB}

Antifungal activity of ergosterol peroxide (1) against $R$. solani AG1-IB was tested as described previously [16] with some modifications. Briefly, pathogen plugs (5-mm diameter) from the growing edges of colonies were placed at the center of Petri dishes containing PDA. Samples of $10 \mu \mathrm{L}$ of the compound at concentrations of $150,300,600$, and $900 \mu \mathrm{g} \cdot$ plug $^{-1}$ were applied on the top of each plug. The negative controls were obtained by applying $10 \mu \mathrm{L}$ of solvent (ethyl acetate) alone. The solvent was evaporated in a laminar flow cabinet, and the plates were incubated at $25^{\circ} \mathrm{C}$ for $48 \mathrm{~h}$. Pathogen growth was measured daily as the colony diameter $(\mathrm{mm})$. Each treatment consisted of three replicates. The percentage of inhibition was calculated based on the following formula: Relative efficacy of inhibition $(\%)=$ (mycelial growth of the control-mycelial growth of the treatment)/mycelial growth of the control $\times 100$.

\subsection{Inhibitory Effect of EtOAc Extracts from Initial Substrate Materials of Bamboo Vermicompost on Mycelium Growth of $R$. solani AG1-IB}

The initial substrate materials of bamboo vermicompost contained bamboo shoots powder and kudzu vine pieces. We examined whether the antifungal compounds in bamboo vermicompost were originally in the initial substrate materials. The bamboo shoots powder or kudzu vine pieces were extracted in $100 \%$ methanol at a ratio of $1: 2(\mathrm{v} / \mathrm{v}$, dry plant material/solvent), and then the organic layer was evaporated. The resultant extracts were suspended in $\mathrm{H}_{2} \mathrm{O}$ and extracted with EtOAc, and then the organic layer was evaporated in vacuo. Bamboo vermicompost was used as a positive control. The EtOAc extracts were used to determinate their antifungal activities against $R$. solani AG1-IB by paper disc diffusion method [14].

\subsection{Data Analysis}

Data are represented in terms of the mean \pm standard error. Comparison between the effect of treatment with SWE and sterilized distilled water on $R$. solani AG1-IB mycelium growth was carried out according to Student's $t$-test $(P<$ 0.05). The other data were evaluated by Tukey's HSD test $(P<0.05)$ using IBM SPSS Statistics 25 (IBM Corp., Armonk, NY, USA). 


\section{Results}

\subsection{Treatment Effect of SWE on Mycelium Growth Rate of $R$. solani AG1-IB}

SWE significantly $(P<0.05)$ inhibited the mycelium growth of $R$. solani AG1-IB on PDA medium as compared to the control (Figure 2(a)). The presence of SWE in PDA medium decreased the fungal growth rate from $23.8 \mathrm{~mm} / 24 \mathrm{~h}$ to $20.3 \mathrm{~mm} / 24 \mathrm{~h}$ (Figure 2 (b)).

\subsection{Isolation of Antifungal Compounds from Bamboo Vermicompost}

The fractions (C, D, E, F and G) showed antifungal activities, whereas the other fractions did not show these effects (Figure 3). The fraction $C$ was chosen for further fractioned as it showed two major peaks (Figure 4). However, no major peaks were observed on the fractions (D, E, F and G) (data not shown). Two compounds, 1 and 2, were obtained from the fraction C. For compound 1, appearing as the major peak (tR $45.78 \mathrm{~min}$ ) shown in Figure 4 was determined as ergosterol peroxide by detailed analysis of the ${ }^{1} \mathrm{H}$ and ${ }^{13} \mathrm{C}$ NMR spectra (Table 1). Compound 2, the minor peak (tR $44.48 \mathrm{~min}$ ) in Figure 4 was determined a

(a)

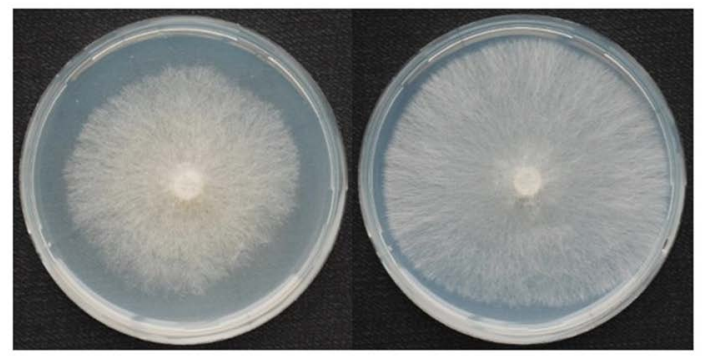

(b)

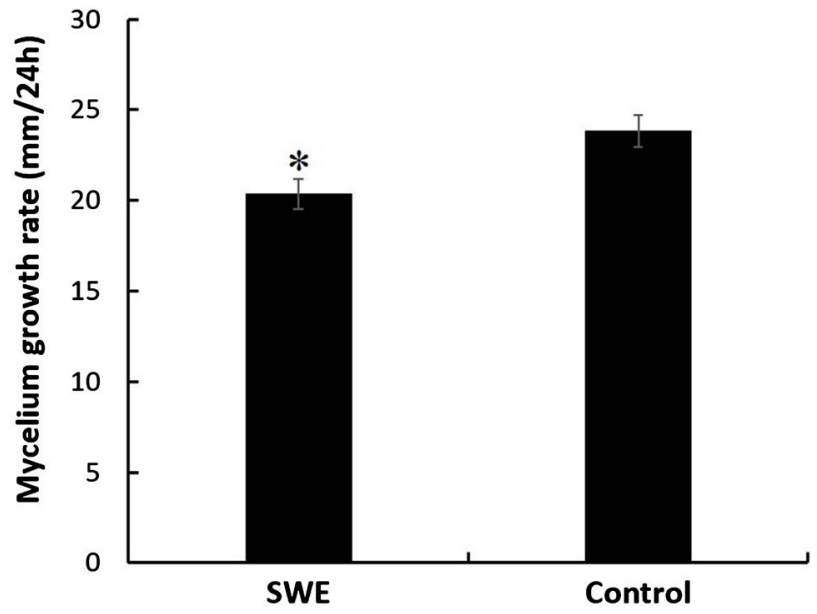

Figure 2. (a) Effect of treatment with SWE on $R$. solani AG1-IB mycelium growth observed on a potato dextrose agar plate. (b) Mycelium growth rate $(\mathrm{mm} / 24 \mathrm{~h})$ of $R$. solani AG1-IB when treated with or without the SWE. Data are the mean values of the results $(N=5)$. The bar at the top of each column represents the standard error of the mean. The asterisk indicates a significant difference compared to the result obtained in the control ( $t$-test, $P<0.05)$. 

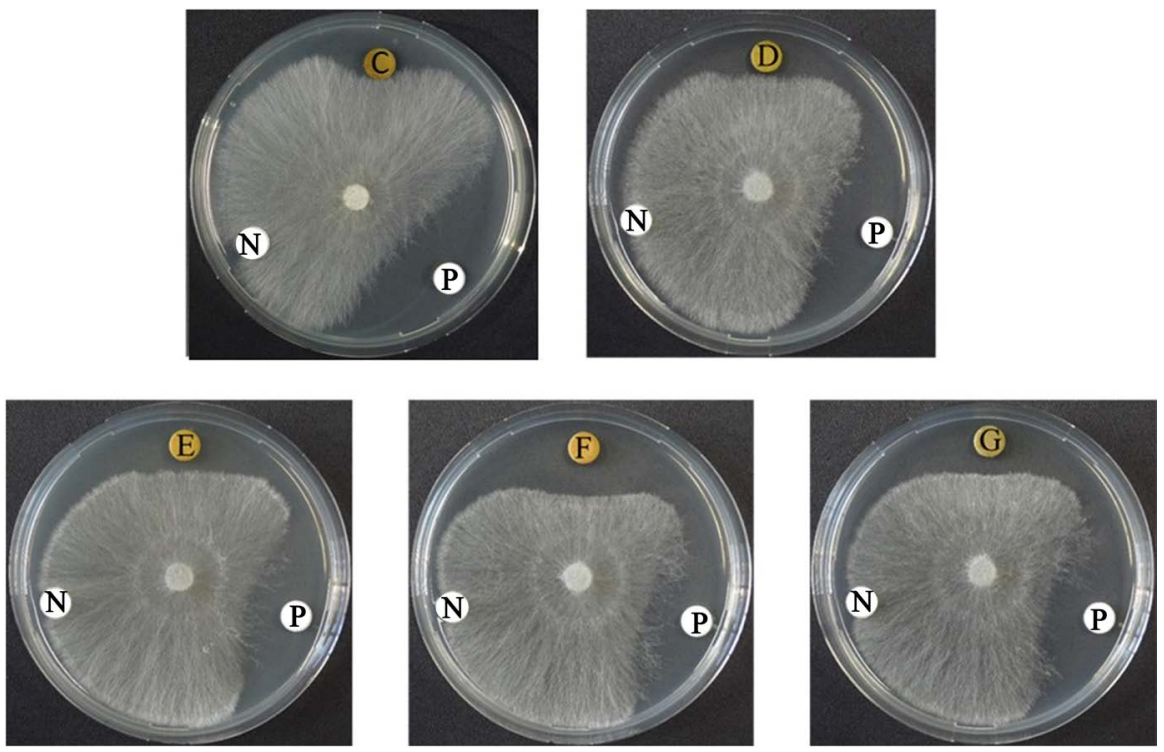

Figure 3. Antifungal activity of the Fr. C, D, E, F, G of EtOAc extracts of bamboo vermicompost acetone extracts against the mycelia growth of $R$. solani AG1-IB on PDA using the paper disc diffusion method. The mycelial growth was observed after 48 hours incubation in the dark at $25^{\circ} \mathrm{C}$. P: Positive control (cycloheximide), N: Negative control (EtOAc alone).

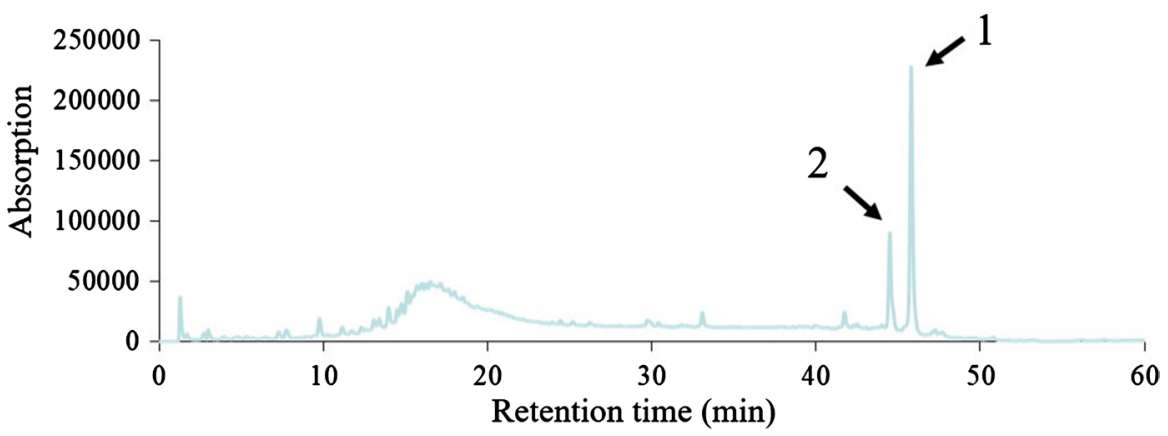

Figure 4. HPLC analysis of the EtOAc fraction $\mathrm{C}$ obtained by silica gel column chromatography of the acetone layer from the bamboo vermicompost.

(22E, 24R)-5 $\alpha, 8 \alpha$-epidioxyergosta-6,9(11),22-trien-3 $\beta$-ol by detailed analysis of the ${ }^{1} \mathrm{H}$ and ${ }^{13} \mathrm{C}$ NMR spectra (Table 2). The physical and chemical properties of the two isolated compounds were as follows:

Compound 1 was obtained as a colorless amorphous powder and the molecular formula was determined as $\mathrm{C}_{28} \mathrm{H}_{44} \mathrm{O}_{3}$ by electrospray ionization-mass spectrometry. The ${ }^{1} \mathrm{H}-\mathrm{NMR}$ spectrum of compound 1 showed four olefinic protons, an oxygenated proton, four doublet methyl protons, and two singlet methyl protons. The number of these methyl groups and coupling patterns suggested that the carbon flame of 1 was ergostane. The ${ }^{13} \mathrm{C}-\mathrm{NMR}$ spectrum showed four $\mathrm{sp}^{2}$ carbons, three oxygenated carbons, and 21 aliphatic carbons, for a total of 28 carbons. From these data compound 1 was assumed to be ergosterol peroxide. Therefore, compound 1 was confirmed to be ergosterol peroxide, as the ${ }^{1} \mathrm{H}$ - and ${ }^{13} \mathrm{C}-\mathrm{NMR}$ data of compound 1 matched previous data [17]. 
Compound 2 was obtained as a colorless amorphous powder and the molecular formula was confirmed to be $\mathrm{C}_{28} \mathrm{H}_{42} \mathrm{O}_{3}$ by electrospray ionization-mass spectrometry. ${ }^{1} \mathrm{H}$ - and ${ }^{13} \mathrm{C}$-NMR spectra of compound 2 were very similar to those of compound 1 except for the appearance of an olefinic proton in the ${ }^{1} \mathrm{H}-\mathrm{NMR}$ spectrum and appearance of two $\mathrm{sp}^{2}$ carbons and disappearance of two aliphatic carbons. Therefore, compound 2 was considered to be an ergosterol peroxide

Table 1. Comparison of the compound 1 obtained in this study and ergosterol peroxide in ${ }^{1} \mathrm{H}$ - and ${ }^{13} \mathrm{C}-\mathrm{NMR}$ data in $\mathrm{CDCl}_{3}$.

\begin{tabular}{|c|c|c|c|c|}
\hline \multicolumn{3}{|c|}{1} & \multicolumn{2}{|c|}{ ergosterol peroxide } \\
\hline atom & $\delta_{\mathrm{C}}$ & $\delta_{\mathrm{H}}(J$ in $\mathrm{Hz})$ & $\delta_{\mathrm{C}}$ & $\delta_{\mathrm{H}}(J$ in $\mathrm{Hz})$ \\
\hline 1 & 35.1 & $1.73 \mathrm{~m} 1.97 \mathrm{~m}$ & 35.1 & $\begin{array}{l}1.71(\mathrm{dd}, 13.5,3.1) \\
1.98(\mathrm{dd}, 13.5,3.1)\end{array}$ \\
\hline 2 & 30.5 & $1.54 \mathrm{~m}, 1.84 \mathrm{~m}$ & 30.5 & $1.55 \mathrm{~m}, 1.85 \mathrm{~m}$ \\
\hline 3 & 66.8 & $3.97 \mathrm{~m}$ & 66.8 & $3.98 \mathrm{~m}$ \\
\hline 4 & 37.3 & $1.92 \mathrm{~m}, 2.11 \mathrm{~m}$ & 37.3 & $1.94 \mathrm{~m}, 2.11 \mathrm{~m}$ \\
\hline 5 & 82.5 & & 83.1 & \\
\hline 6 & 135.8 & $6.25(\mathrm{~d}, 8.6)$ & 135.8 & $6.25(\mathrm{~d}, 8.6)$ \\
\hline 7 & 131.1 & $6.51(\mathrm{~d}, 8.6)$ & 131.1 & $6.51(\mathrm{~d}, 8.6)$ \\
\hline 8 & 79.8 & & 79.8 & \\
\hline 9 & 51.4 & $1.50 \mathrm{~m}$ & 51.4 & $1.50 \mathrm{~m}$ \\
\hline 10 & 37.3 & & 37.3 & \\
\hline 11 & 23.8 & $1.23 \mathrm{~m}, 1.55 \mathrm{~m}$ & 23.8 & $1.22 \mathrm{~m}, 1.53 \mathrm{~m}$ \\
\hline 12 & 39.7 & $1.25 \mathrm{~m}, 1.98 \mathrm{~m}$ & 39.7 & $1.25 \mathrm{~m}, 1.96 \mathrm{~m}$ \\
\hline 13 & 44.9 & & 44.9 & \\
\hline 14 & 52.1 & $1.59 \mathrm{~m}$ & 52.1 & $1.57 \mathrm{~m}$ \\
\hline 15 & 21.0 & $1.42 \mathrm{~m}, 1.66 \mathrm{~m}$ & 21.0 & $1.40 \mathrm{~m}, 1.66 \mathrm{~m}$ \\
\hline 16 & 29.0 & $1.35 \mathrm{~m}, 1.79 \mathrm{~m}$ & 29.1 & $1.35 \mathrm{~m}, 1.80 \mathrm{~m}$ \\
\hline 17 & 56.6 & $1.23 \mathrm{~m}$ & 56.6 & $1.24 \mathrm{~m}$ \\
\hline 18 & 13.1 & $0.82 \mathrm{~s}$ & 13.3 & $0.83 \mathrm{~s}$ \\
\hline 19 & 18.6 & $0.88 \mathrm{~s}$ & 18.6 & $0.89 \mathrm{~s}$ \\
\hline 20 & 40.1 & $2.01 \mathrm{~m}$ & 40.1 & $2.05 \mathrm{~m}$ \\
\hline 21 & 21.3 & $1.00(\mathrm{~d}, 6.9)$ & 21.3 & $1.00(\mathrm{~d}, 6.6)$ \\
\hline 22 & 135.6 & $5.14(\mathrm{dd}, 15.2,8.3)$ & 135.6 & $5.15(\mathrm{dd}, 15.2,7.7)$ \\
\hline 23 & 132.7 & $5.22(\mathrm{dd}, 15.2,7.6)$ & 132.4 & $5.22(\mathrm{dd}, 15.2,8.2)$ \\
\hline 24 & 43.1 & $1.86 \mathrm{~m}$ & 43.1 & $1.85 \mathrm{~m}$ \\
\hline 25 & 33.4 & $1.46 \mathrm{~m}$ & 33.4 & $1.50 \mathrm{~m}$ \\
\hline 26 & 20.0 & $0.82(\mathrm{~d}, 6.9)$ & 20.0 & $0.82(\mathrm{~d}, 6.7)$ \\
\hline 27 & 20.3 & $0.83(\mathrm{~d}, 6.9)$ & 20.3 & $0.84(\mathrm{~d}, 6.7)$ \\
\hline 28 & 17.9 & $0.91(\mathrm{~d}, 6.9)$ & 18.0 & $0.91(\mathrm{~d}, 6.7)$ \\
\hline
\end{tabular}


Table 2. Comparison of compound 2 and $(22 E, 24 R)-5 \alpha, 8 \alpha$-epidioxyergosta 6,9(11),22trien-3 $\beta$-ol in ${ }^{1} \mathrm{H}$ - and ${ }^{13} \mathrm{C}-\mathrm{NMR}$ data in $\mathrm{CDCl}_{3}$.

\begin{tabular}{|c|c|c|c|c|}
\hline \multirow[b]{2}{*}{ atom } & \multicolumn{2}{|l|}{2} & \multicolumn{2}{|c|}{$\begin{array}{c}(22 E, 24 R)-5 \alpha, 8 \alpha \text {-epidioxyergosta- } \\
6,9(11), 22 \text {-trien- } 3 \beta \text {-ol }\end{array}$} \\
\hline & $\delta_{\mathrm{C}}$ & $\delta_{\mathrm{H}}(J$ in $\mathrm{Hz})$ & $\delta_{\mathrm{C}}$ & $\delta_{\mathrm{H}}(J$ in $\mathrm{Hz})$ \\
\hline 1 & 32.5 & & 32.5 & \\
\hline 2 & 30.6 & & 30.5 & \\
\hline 3 & 66.3 & $4.01 \mathrm{~m}$ & 66.3 & $4.01 \mathrm{~m}$ \\
\hline 4 & 36.0 & & 36.0 & \\
\hline 5 & 82.7 & & 82.7 & \\
\hline 6 & 135.4 & $6.29(\mathrm{~d}, 8.3)$ & 135.4 & $6.27(\mathrm{~d}, 8.4)$ \\
\hline 7 & 130.7 & $6.60(\mathrm{~d}, 8.3)$ & 130.7 & $6.58(\mathrm{~d}, 8.4)$ \\
\hline 8 & 78.3 & & 78.3 & \\
\hline 9 & 142.5 & & 142.4 & \\
\hline 10 & 37.9 & & 37.9 & \\
\hline 11 & 119.7 & $5.43(\mathrm{dd}, 5.8,1.5)$ & 11.97 & $5.41(\mathrm{dd}, 6.0,0.8)$ \\
\hline 12 & 41.2 & & 41.1 & \\
\hline 13 & 43.6 & & 43.6 & \\
\hline 14 & 48.1 & & 48.1 & \\
\hline 15 & 20.9 & & 20.8 & \\
\hline 16 & 28.6 & & 28.7 & \\
\hline 17 & 55.8 & & 55.8 & \\
\hline 18 & 12.9 & $0.74 \mathrm{~s}$ & 12.9 & $0.71 \mathrm{~s}$ \\
\hline 19 & 25.5 & $1.09 \mathrm{~s}$ & 25.5 & $1.06 \mathrm{~s}$ \\
\hline 20 & 39.9 & & 39.9 & \\
\hline 21 & 20.7 & $1.00(\mathrm{~d}, 6.9)$ & 20.7 & $0.98(\mathrm{~d}, 6.4)$ \\
\hline 22 & 135.1 & $5.17(\mathrm{dd}, 15.5,8.3)$ & 135.1 & $5.15(\mathrm{dd}, 15.2,7.2)$ \\
\hline 23 & 132.4 & $5.25(\mathrm{dd}, 15.5,8.3)$ & 132.4 & $5.27(\mathrm{dd}, 15.2,8.0)$ \\
\hline 24 & 42.7 & & 42.7 & \\
\hline 25 & 33.0 & & 33.0 & \\
\hline 26 & 19.9 & $0.84(\mathrm{~d}, 6.9)$ & 19.9 & $0.81(\mathrm{~d}, 6.8)$ \\
\hline 27 & 19.6 & $0.82(\mathrm{~d}, 6.9)$ & 19.6 & $0.80(\mathrm{~d}, 6.4)$ \\
\hline 28 & 17.5 & $0.92(\mathrm{~d}, 6.9)$ & 17.5 & $0.89(\mathrm{~d}, 6.8)$ \\
\hline
\end{tabular}

derivative with one additional double bond. The compound (22E, 24R)-5 $\alpha, 8 \alpha$ epidioxyergosta-6,9(11),22-trien-3 $\beta$-ol satisfied the above data. Therefore, the ${ }^{1} \mathrm{H}$ - and ${ }^{13} \mathrm{C}-\mathrm{NMR}$ data of compound 2 were compared to previous data [18]. Compound 2 was identified as (22E, 24R)-5a,8 $\alpha$-epidioxyergosta-6,9(11),22-trien$3 \beta$-ol, based on these data showing very good agreement.

The structures of the compounds 1 and 2 are shown in Figure 5. Compound 1 was then assayed for antifungal activity against $R$. solani AG1-IB, but compound 2 was not tested because of its insufficient amount. 


\subsection{Inhibitory Effect of Ergosterol Peroxide (1) Isolated from Bamboo Vermicompost on Mycelium Growth of $R$. solani AG1-IB}

Mycelial growth by $R$. solani AG1-IB was found to decrease gradually in response to increasing doses of ergosterol peroxide from 150 to $900 \mu \mathrm{g}$ (Figure 6(a)). Ergosterol peroxide at 150, 300, 600, and $900 \mu \mathrm{g}$ showed 13\%, 22\%, 34\%, and 53\% mycelial growth inhibition of $R$. solani AG1-IB, respectively, as compared to control (Figure 6(b)).

\subsection{Inhibitory Effect of EtOAc Extracts from Initial Substrate Materials of Bamboo Vermicompost on Mycelium Growth of $R$. solani AG1-IB}

The EtOAc extracts from bamboo vermicompost inhibited the mycelium growth of $R$. solani AG1-IB, whereas those from bamboo shoots powder and kudzu

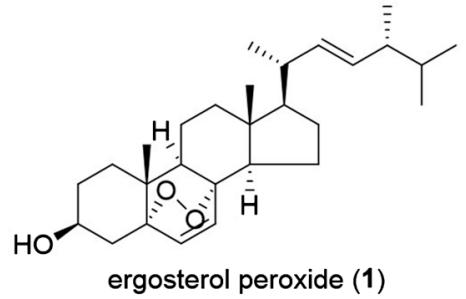

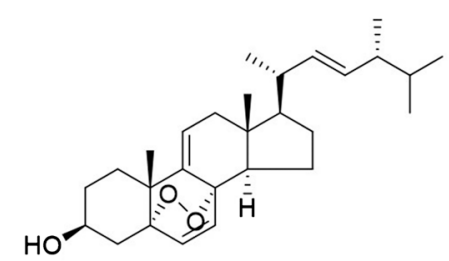

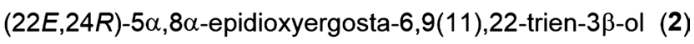

Figure 5. Structures of compounds $\mathbf{1}$ and $\mathbf{2}$ isolated from bamboo vermicompost.

(a)

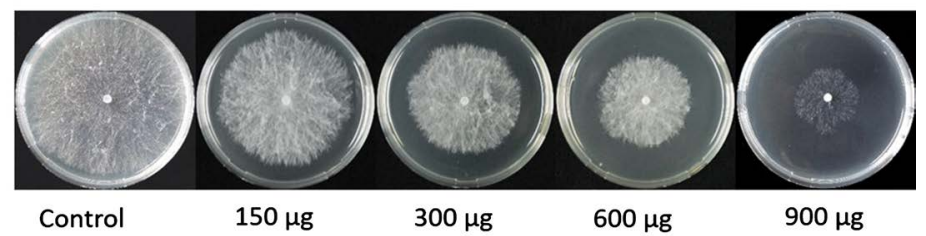

(b)

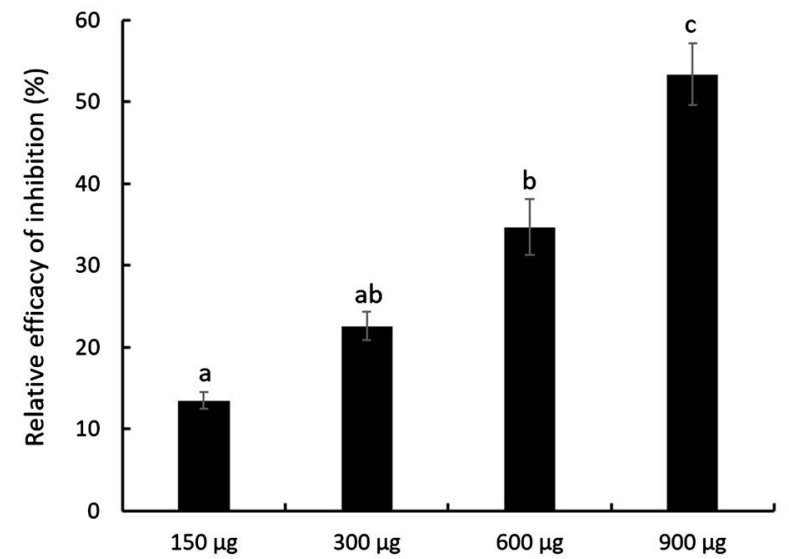

Figure 6. Inhibitory effects of the ergosterol peroxide on the mycelial growth of $R$. solani AG1-IB on PDA media. Radial growth of mycelia was measured after $48 \mathrm{~h}$ of inoculation. (a) Photos; (b) Relative efficacy of inhibition (\%). Samples of $10 \mu \mathrm{L}$ of ergosterol peroxide at concentrations of 150,300, 600 and $900 \mu \mathrm{g} \cdot \mathrm{plug}^{-1}$ were applied on top of each plug $(N$ $=3)$. Bars with different letters were significant according to Tukey's HSD test $(P<0.05)$. 

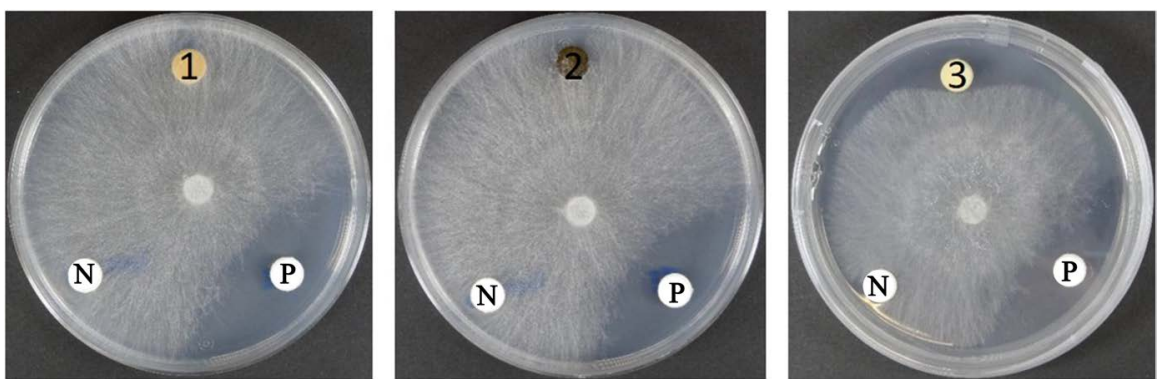

Figure 7. Antifungal activity of crude EtOAc extracts from bamboo shoots powder (1), kudzu vines (2), and bamboo vermicompost (3). The crude EtOAc extracts were placed on paper discs. P: Positive control (cycloheximide), N: Negative control (EtOAc alone).

vines did not show these effects (Figure 7).

\section{Discussion}

Rhizoctonia solani, one of the most common soil-borne plant pathogenic fungi worldwide, causes serious economic losses of different crops and its control strategies rely mainly on chemical fungicide applications. An eco-friendly disease management strategy is urgently needed. Vermicompost has become a promising alternative to chemical pesticide because of its disease suppression effects. However, the mechanisms of how vermicompost activity in plant disease suppression are not well-understood [19]. Antifungal compounds, which are released by beneficial organisms in the vermicompost, may play an important role in inhibiting plant pathogens; however, these mechanisms have not been widely examined. Although $\mathrm{Mu}$ et al. (2017) showed that some volatile organic compounds, such as 3-methyl-3-hexanol, released by Bacillus subtilis isolated from a cow dung based vermicompost showed significant inhibitory activity against Botrytis cinerea [8], no antifungal compounds have been isolated directly from vermicompost.

In this study, five EtOAc fractions (C, D, E, F and G), obtained by silica gel column chromatography of the acetone layer from the bamboo vermicompost showed antifungal activities against $R$. solani AG1-IB. Two known compounds were obtained from the fraction $(C)$ showing two major peaks and characterized as ergosterol peroxide (1) and $(22 E, 24 R)-5 \alpha, 8 \alpha$-epidioxyergosta-6,9(11), 22 -trien-3 $\beta$-ol (2). This is the first study to isolate these two compounds from vermicompost. The mycelium growth of $R$. solani AG1-IB was significantly suppressed by ergosterol peroxide. The antifungal capacity of ergosterol peroxide against $R$. solani was demonstrated in this study. The EtOAc extracts from bamboo vermicompost inhibited $R$. solani AG1-IB mycelium growth, whereas those from the original substrates did not, including bamboo shoots powder and kudzu vines. This result suggests that the antifungal compounds in vermicompost were released by microbes in the vermicompost during vermicomposting, but not from the original substrates. This agrees with a previous study demonstrating that filter sterilized aqueous extract of vermicompost prepared from paper sludge and dairy sludge significantly inhibited the spore germination of $\mathrm{Fu}$ - 
sarium moniliforme as compared to the aqueous extract of filter sterilized aqueous extract of the fresh sludge [20].

Ergosterol peroxide is a non-volatile compound that has been isolated from various species of mushrooms, microscopic fungi such as Trichoderma longibrachiatum, and yeasts, and has been reported to exhibit antitumor, anti-inflammatory and antimicrobial activities in vitro [21] [22]. Some of the producers of ergosterol peroxide likely actively grow in the vermicompost. However, the antifungal compounds in the other EtOAc fractions, including D, E, F, and $G$, have not yet been identified. Further studies are required to identify these antifungal compounds and determine their suppressive effects on seedling damping-off diseases caused by $R$. solani. In this study, we demonstrated that vermicompost inhibited the development of fungal pathogens through the antifungal compounds present in it, which may promote effective utilization of vermicompost.

\section{Conclusion}

In conclusion, several antifungal compounds were present in the bamboo vermicompost, which were released by microbes, and played an important role in inhibiting plant pathogens. Ergosterol peroxide isolated from the vermicompost, showed significant in vitro inhibitory effect on mycelium growth of $R$. solani AG1-IB.

\section{Acknowledgements}

This work is in parts supported by JSPS KAKENHI (Grant No. 19J10250) and the Graduate Program for System-inspired Leaders in Material Science (SiMS) of Osaka Prefecture University by the Ministry of Education, Culture, Sports, Science and Technology of Japan, and JA Bank Osaka Industry-University Cooperation Project and Geol Cosmetics Co. Ltd. The authors thank Dr. Misawa Tomoo for providing the Rhizoctonia solani isolate, and Mr. Yukihiro Shimogami of Kawachinagano City Office and Eboshi-yama Satoyama Conservation Club for bamboo powder.

\section{Conflicts of Interest}

The authors declare no conflicts of interest regarding the publication of this paper.

\section{References}

[1] Abbasi, P.A., Conn, K.L. and Lazarovits, G. (2004) Suppression of Rhizoctonia and Pythium Damping-Off of Radish and Cucumber Seedlings by Addition of Fish Emulsion to Peat Mix or Soil. Canadian Journal of Plant Pathology, 26, 177-187. https://doi.org/10.1080/07060660409507129

[2] Lewis, J.A. and Lumsden, R.D. (2001) Biocontrol of Damping-Off Greenhouse-Grown Crops Caused by Rhizoctonia solani with a Formulation of Trichoderma spp. Crop Protection, 20, 49-56. 
https://doi.org/10.1016/S0261-2194(00)00052-1

[3] Ogoshi, A. (1996) Introduction-The Genus Rhizoctonia solani. In: Sneh, B., Jabaji-Hare, S., Neate, S.M. and Dijst, G., Eds., Rhizoctonia Species, Taxonomy, Molecular Biology, Ecology: Pathology and Disease Control, Kluwer, Dordrecht, 1-9. https://doi.org/10.1007/978-94-017-2901-7_1

[4] Becker, J.O., Ohr, H.D., Grech, N.M., McGiffen, M.E.J. and Sims, J.J. (1998) Evaluation of Methyl Iodide as a Soil Fumigant in Container and Smallfield Plot Studies. Pesticide Science, 52, 56-62. https://doi.org/10.1002/(SICI)1096-9063(199801)52:1<58::AID-PS632>3.0.CO;2-Y

[5] Campion, C., Chatot, C., Perraton, B. and Andrivon, D. (2003) Anastomosis Groups, Pathogenicity and Sensitivity to Fungicides of Rhizoctonia solani Isolates Collected on Potato Crops in France. European Journal of Plant Pathology, 109, 983-992. https://doi.org/10.1023/B:EJPP.0000003829.83671.8f

[6] Chaoui, H., Edwards, C.A., Brickner, A., Lee, S. and Arancon, N.Q. (2002) Suppression of the Plant Diseases, Pythium (Damping-Off), Rhizoctonia (Root Rot) and Verticillium (Wilt) by Vermicomposts. Brighton Crop Protection Conference Pests and Diseases, Vol. 8, 711-716.

[7] Ersahin, Y.S., Haktanir, K. and Yanar, Y. (2009) Vermicompost Suppresses Rhizoctonia solani Kühn in Cucumber Seedlings. Journal of Plant Diseases and Protection, 116, 182-188. https://doi.org/10.1007/BF03356308

[8] Mu, J., Li, X., Jiao, J., Ji, G., Wu, J., Hu, F. and Li, H. (2017) Biocontrol Potential of Vermicompost through Antifungal Volatiles Produced by Indigenous Bacteria. Biological Control, 112, 49-54. https://doi.org/10.1016/j.biocontrol.2017.05.013

[9] Gopalakrishnan, S., Pande, S., Sharma, M., Humayun, P., Kiran, B.K., Sandeep, D., Vidya, M.S., Deepthi, K. and Rupela, O. (2011) Evaluation of Actinomycete Isolates Obtained from Herbal Vermicompost for the Biological Control of Fusarium Wilt of Chickpea. Crop Protection, 30, 1070-1078. https://doi.org/10.1016/j.cropro.2011.03.006

[10] Barocio-Ceja, N.B., Ceja-Torres, L.F., Morales-García, J.L., Silva-Rojas, H.V., Flores-Magallón, R. and Ochoa-Estrada, S. (2013) In Vitro Biocontrol of Tomato Pathogens Using Antagonists Isolated from Chicken-Manure Vermicompost. Phyton, International Journal of Experimental Botany, 82, 15-22.

[11] You, X.D., Kimura, N., Okura, T., Murakami, S., Okano, R., Shimogami, Y., Matsumura, A., Tokumoto, H., Ogata, Y. and Tojo, M. (2019) Suppressive Effects of Vermicomposted-Bamboo Powder on Cucumber Damping-Off. JARQ, 53, 13-19. https://doi.org/10.6090/jarq.53.13

[12] Misawa, T., Hagiwara, A., Ohhira, M. and Yamaguchi, T. (2016) Subgroup Identification of Rhizoctonia solani, the Causal Agent of Spinach Foot Root, and Pathogenicity Comparison of the Pathogens with the Isolates Belonging to Related Subgroups to Spinach. Annual Report of the Society of Plant Protection of North Japan, 67, 94-99.

[13] Ebrahimi, E., Werren, D. and Niemsdorff, P.V.F. (2018) Suppressive Effect of Composts from Residual Biomass on Pythium ultimum. Journal of Plant Diseases and Protection, 125, 443-449. https://doi.org/10.1007/s41348-018-0163-7

[14] Nguyen, V.N., Nguyen, D.M.C., Seo, D.J., Park, R.D. and Jung, W.J. (2009) Antimycotic Activities of Cinnamon-Derived Compounds against Rhizoctonia solani in Vitro. BioControl, 54, 697-707. https://doi.org/10.1007/s10526-009-9220-2

[15] Ishikawa, K., Takahashi, K., Hosoi, S., Takeda, H., Yoshida, H., Wakana, D., Tsubuki, M., Sato, F., Tojo, M. and Hosoe, T. (2019) Antimicrobial Agent Isolated from 
Coptidis rhizome Extract Incubated with Rhodococcus sp. Strain BD7100. The Journal of Antibiotics, 72, 71-78. https://doi.org/10.1038/s41429-018-0114-3

[16] Vinale, F., Flematti, G., Sivasithamparam, K., Lorito, M., Marra, R., Skelton, B.W. and Ghisalberti, E.L. (2009) Harzianic Acid, an Antifungal and Plant Growth Promoting Metabolite from Trichoderma harzianum. Journal of Natural Products, 72, 2032-2035. https://doi.org/10.1021/np900548p

[17] Kim, D.S., Baek, N.I., Oh, S.R., Jung, K.Y., Lee, I.S., Hee, J. and Lee, H.K. (1997) Anticomplementary Activity of Ergosterol Peroxide from Naematoloma fasciculare and Reassignment of NMR Data. Archives of Pharmacal Research, 20, 201-205. https://doi.org/10.1007/BF02976145

[18] Du, Z.Z. and Shen, Y.M. (2016) A Rare New Cleistanthane Diterpene from the Pericarp of Trewia nudiflora. Helvetica Chimica Acta, 89, 2841-2845.

https://doi.org/10.1002/hlca.200690256

[19] Simsek-Ersahin, Y. (2011) The Use of Vermicompost Products to Control Plant Diseases and Pests. In: Karaca, A., Ed., Biology of Earthworms, Springer, Berlin, 191-213. https://doi.org/10.1007/978-3-642-14636-7_12

[20] Yasir, M., Aslam, Z., Kim, S.W., Lee S.W., Jeon, C.O. and Chung, Y.R. (2009) Bacterial Community Composition and Chitinase Gene Diversity of Vermicompost with Antifungal Activity. Bioresource Technology, 100, 4396-4403.

https://doi.org/10.1016/j.biortech.2009.04.015

[21] Krzyczkowski, W., Malinowska, E., Suchocki, P., Kleps, J., Olejnik, M. and Herold, F. (2009) Isolation and Quantitative Determination of Ergosterol Peroxidein Various Edible Mushroom Species. Food Chemistry, 113, 351-355. https://doi.org/10.1016/j.foodchem.2008.06.075

[22] Ji, Z.L., Ma, D.S. and Miao, F.P. (2014) Chemical Constituents from Trichoderma longibrachiatum, an Endophytic Fungus Derived from Marine Green Alga Codium fragile. Journal of Shenyang University, 26, 277-280, 319. 